\title{
KENYA'S STANDARD GAUGE RAILWAY PROJECT IN THE CONTEXT OF THEORY AND PRACTICE OF REGIONAL PLANNING
}

\author{
Juma Leanard Otwori - Adol Gogo Fredrick - Abdulkadr Ahmed Abduletif - \\ Lóránt Dénes Dávid
}

\begin{abstract}
Despite most African countries having immense natural and human resources potential, the continent has mostly been lagging on matters of economic development. This scenario could primarily be attributed to weak intra-regional and inter-country trade given the poor connectivity, quality, and diversity in transportation services and infrastructure. In this regard, the governments of the greater East African Region representing Tanzania, Rwanda, Burundi, Uganda, South Sudan, Ethiopia and Kenya, therefore, mooted a coordinated vision to develop interlinked regional infrastructure in road and rail transport to allow smooth movement of goods and services. This paper aimed to critically review the impact of the SGR development on Kenya in the context of regional planning and development. The methodology of the study was a critical review of existing literature and secondary data. Study findings indicated that the development of the (Standard Gauge Railway) SGR is in tandem with the development strategies of other East African Countries. Its development is incorporated in national spatial plans with the rail route targeting regions with viable populations and sustainable economic activities. Criticisms, however, revolve around the ballooning debt to finance infrastructural development and lack of prioritization $f$ mega projects. In conclusion, despite the financial constraints, the SGR is viewed to significantly influence the socio-economic spheres while presenting challenges in the management of landscapes where it traverses in Kenya and the Region.
\end{abstract}

Keywords: transportation, Kenya, regional planning, standard gauge railway JEL: $R 42$ 


\section{Introduction}

Despite most African countries having immense natural and human resources, the continent has mostly been lagging on matters of economic development. This scenario could primarily be attributed to weak intraregional and intercountry trade and movement of goods and services given the poor connectivity, quality, and diversity in transport infrastructure and services. It is worse for landlocked countries where products have great difficulty in accessing external markets or external products reaching their regions, and when they do, the pricing will not be competitive enough to generate sufficient revenue for businesses resulting to slow economic growth. Good transport infrastructure is key in facilitating the smooth flow of goods and services and even capital across regions, countries, and continents for economic growth and development.

Consequently, the governments of the greater East African Region constituting of Tanzania, Rwanda, Burundi, Uganda, South Sudan, Ethiopia and Kenya, mooted a coordinated vision to develop regional infrastructure in road and rail transport to allow smooth movement of goods and services (Fig 1). The countries have a combined market of over 300 million people and it is envisaged that the regional rail and road transport infrastructure will stir socio-economic developments in the broader East African Region (National Council for Population and Development, 2017; World Bank, 2019).

\section{Materials and Methods}

The study employed a critical review of existing literature and secondary data as its methodology. Document analysis was used targeting Kenya's government policy documents and development plans, project progress reports from Kenya's Ministry of Transport, Kenya Railways Corporation, and the print media. The documents provided details of when the project was started, the financing, its progress, projected, and actual impact of the project to the regions it traversed and beyond. 


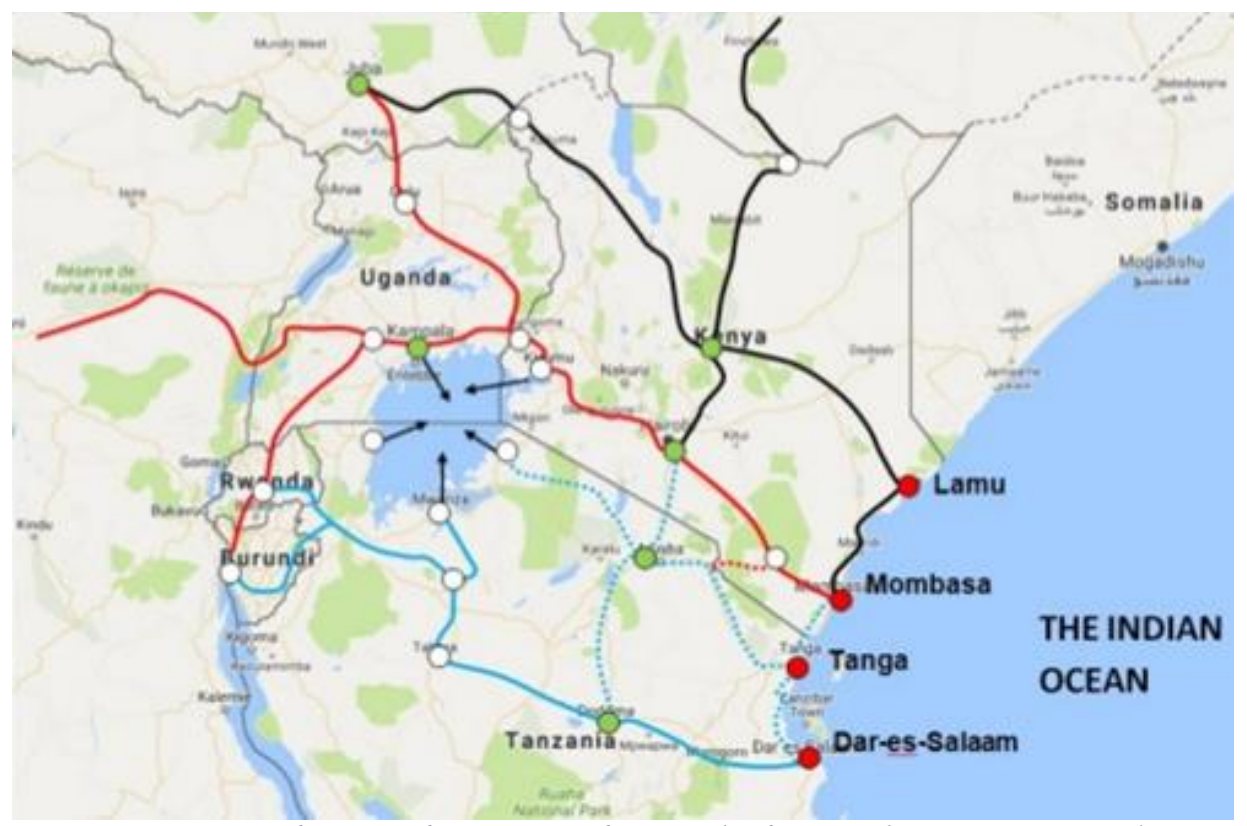

Fig. 1; Existing and proposed Eastern and Central Africa Rail transport network (Key:

-- Southern corridor, -- Northern Corridor, -- Lamu Port South Sudan Ethiopia

Transport Corridor-LAPSSET)

Source: The Republic of Kenya, 2015

\section{Standard Gauge Railway (SGR) Development in Kenya}

Kenya's SGR project was identified as one of the Vision 2030 priority projects that was viewed to play an essential part in consolidating cooperation amongst the East Africa Community member states. Bulk freight flow including coal, containers, petroleum products, fuel oil, cement and its ingredients are transported to Malaba and beyond from Nairobi and Mombasa Port. This will also include few goods produced in townships and outlying areas along the line in addition to providing local passenger transport services. The SGR is viewed as a critical milestone development that will boost Kenya's road and rail transport networks. The freight and passenger traffic that will be taken up by the SGR will reduce the number of vehicles on crucial highways and associated repair costs. It will also be good for environmental protection and reduced road accidents and the duration of transporting products within Kenya and its neighbouring countries. The project has been captured in the Kenya National Transport Policy - 'moving a working nation' (2009) whose overarching vision for rail transport is provision of reliable, safe, and efficient services that are linked-up 
with countrywide and regional road and rail networks, water, pipeline, and air transportation networks for the flow of passengers and freight in a cheaper and efficient manner (Kenya Railways Corporation, 2019).

In 2008, Kenya adopted Vision 2030 with the broad goal of transforming the country into a "newly industrialized, middle-income country offering quality life to its populace in a hygienic and safe environment by 2030. Kenya established this policy through participatory consultative forum that ensured inclusivity of Kenyans and stakeholders founded on the social, economic, and political pillars. This vision was adopted after Kenya's GDP grew from $0.6 \%$ to $6.1 \%$ in 2002 and 2006 respectively under the framework of the Economic Recovery Strategy for Wealth and Employment Creation (ERS) (The Republic of Kenya, 2005; The Republic of Kenya, 2015).

In order to accelerate this economic growth, Vision 2030 proposed several infrastructural investments that will stir more significant economic activity and movement of people, goods, and services. For instance, the SGR for passenger and freight movement between Mombasa port and the hinterland cities like Nairobi, Kisumu, and ultimately to Malaba town along the Kenya-Uganda border. The SGR project has two stages of development: phase one being Mombasa-Nairobi, and phase two Nairobi-Malaba that is further split into three sections: Nairobi Naivasha, NaivashaKisumu, and Kisumu-Malaba. Phase one and section one of the second phase (Nairobi-Naivasha) of the SGR project are already complete and operational. The completed first phase of the project is considered Kenya's most significant infrastructure projects since independence, built at USD 3.27 billion (Kenya Railways Corporation, 2019). The SGR tracks are virtually parallel to the existing one-metergauge Kenya-Uganda Railway between Mombasa and Nairobi. However, for the SGR, long sections of the railway were built on embankments, bridges, and cuttings to manage challenging terrain, while some sections involved tunnelling like the EmBulbul-Naivasha tunnel developed as a single-track underpass of $7.6 \mathrm{~m}$ clearance height and a width of $6.4 \mathrm{~m}$.

Once the Mombasa - Malaba stretch is completed, over half of Kenya's 47 counties will be opened up for economic transformation. This in addition to the LAPSSET corridor will cover more than $75 \%$ of Kenyan counties by transportation network. This infrastructure, alongside the ongoing road and air transport upgrading will linkup major economic zones and towns in Kenya.

The second section of Kenya SGR phase two remains uncertain following the lack of funding from local or international development partners. Kenya is now scouting for other sources of development finance partnerships, including and not limited to the World Bank, Africa Development Bank, and the United States of America. The 1,500km-long SGR line planned from Mombasa to Kigali was scheduled for completion by 2018. However, Kenya has finished half the project distance 
from Mombasa to Naivasha through Nairobi making the Second phase from Nairobi to Malaba to stall at Narok/Naivasha due to a lack of funds.

Cross border cooperation is also an important question (Dávid et al., 2008; Bujdosó et al., 2015). On the regional level, although part of this more extensive regional rail network, Rwanda focused on the Isaka-Kigali railway project more in an attempt to link the capital Kigali with Tanzania. The construction of the $571 \mathrm{Km}$ railway started in December 2018, will improve trade between the Tanzania and Rwanda. The project is estimated to cost USD 2.5 billion and shared between the two countries. Rwanda views this as a cheaper option than if the SGR took the Kenyan route, through Uganda (The Standard, 2014). The Ugandan section of the SGR was launched in October 2014, and feasibility studies and designs completed for the section between Kampala and Malaba in Kenya, the construction is yet to commence, with Uganda ascribing the delayed project to lack of funds and Kenya's failure to finish constructing the Naivasha-Malaba extension of the SGR project.

\section{Discussion of Findings}

\section{Positive Impact of the SGR development}

The Mombasa-Nairobi stretch of the SGR commenced construction in November 2013 and was 90\% funded by the China Exim Bank, and Kenya funding the remainder. Construction of Mombasa-Nairobi SGR was concluded and commenced operations after the launch of the passenger and freight service trains on $1^{\text {st }}$ January 2018. The SGR was designed to support an axle load of 25 tonnes and projected to transport 22million tonnes of freight annually at top speeds of $100 \mathrm{~km} / \mathrm{hr}$ for freight trains and $120 \mathrm{~km} / \mathrm{hr}$ for passenger trains (Kenya Railways Corporation, 2019).

These notwithstanding, the SGR project is anticipated to bring several economic and social benefits. First, the SGR will provide a reliable, fast, and efficient transportation mode. It will decongest Mombasa port by guaranteeing arriving cargo is moved to the hinterlands without delay. A fast and efficient transport will facilitate the smooth movement of goods within Kenya and the broader East African Region. This will offer more productivity, efficiency, and development for producers and consumers and markets, stable prices and steady supply of merchandise and services. Consequently, the SGR shall speed up industrialization by means of cheaper, fast, and efficient transport that will further catalyse the development of new businesses to benefit the new railway.

Secondly, SGR will reduce cargo transportation costs between the Mombasa port, hinterland of Kenya and the East African Region. The Kenya Railways Corporation (KRC), observes that it will cost USD 500 to convey freight containers 
through SGR cargo compared to USD 900 by road from Mombasa to Nairobi (Kenya Railways Corporation, 2019). Reduced transportation costs will boost local businesses and other sectors like manufacturing, agriculture, building and construction due to significant reduction in costs of production and distribution of goods and industrialization within Kenya and East African Region. The multiplier effect of cheap and efficient transport system is the growth in more inter- and intraregional trade and, therefore, economic growth and development. Indeed according to the Kenya government, the new railway is expected to boost growth in GDP by $1.5 \%$ throughout its operation (Ministry of Transport, Infrastructure Housing, Urban Development, and Public Works, 2019).

The SGR project compared to bus trips between Nairobi and Mombasa, will allow passengers to enjoy a quicker and cheaper journey. The travel times will be reduced by half from the current 8 hours' bus transport experience to a cheaper and faster means. With an average of $99.1 \%$ occupancy rate (including inter-county seats reuse), the Mombasa-Nairobi SGR route has not only effectively solved the supply and demand dis-equilibrium but has also increased KRC's revenue. SGR is acknowledged as the biggest transport infrastructure project in the country's history that targets to provide low-cost and efficient mobility of cargo and passengers moving fourteen freight and four passenger trains a day. SGR transport 4500 passengers and about 800 cargo containers per day between the cities of Mombasa and Nairobi (Ilako, 2019).

The amount of passengers and cargo containers transported daily by the SGR would substantially reduce the number of heavy goods vehicles on the road, thereby helping to protect the environment by reducing carbon emissions. According to the Kenya Truckers Association and the Ministry of Transport, over 1300 heavy haulage trucks are off the road and more will be, once double-stack trains are introduced and expansions of the holding capacity of Nairobi Inland container depot is done, (Ministry of Transport, Infrastructure Housing, Urban Development, and Public Works, 2019). Once the entire stretch of the SGR line to western Kenya town of Malaba is completed, more tracks will be off the road hence, more reduction on emissions from the diesel-powered trucks hauling freight from Mombasa, Nairobi to Malaba and beyond. There will be further reduction in environmental emissions when SGR will be upgraded to electricity-powered engines as opposed to diesel.

Similar to the arrival of the lunatic express between 1896 and 1902 that resulted in growth of towns along its route, a major effect of the SGR on the Kenyan landscape and economy will be the advent of towns starting from its 33 train stations as well as re-invigoration of commercial activities in already existing towns (Mwende, 2017; Nduire, 2018). Agricultural produce and, in particular, horticulture and floriculture farmers in Naivasha and surrounding areas would have cheaper and faster transportation to Jomo Kenyatta International Airport for their goods via the 
Naivasha Internal Container Depot. Fresh produce will get faster into the local and international markets, helping these businesses to grow further and employ more people.

Phase two of the project will also dramatically change the face of Nakuru County and drive the economies of the cities of Nakuru and Naivasha, which have been ignored in terms of infrastructure development for years. Kwale, Mombasa, Taita Taveta, Makueni, Machakos, Kajiado, Nairobi, Kiambu, Narok, and Nakuru counties will experience similar economic renaissance occasioned by the SGR. Once completed, the Mombasa- Malaba SGR will cover a total of 18 out of Kenya's 47 counties to include Bomet, Kericho, Nyamira, and Kisumu county, where an inland seaport is set up for regional trade and commerce through Lake Victoria to Tanzania, Uganda and neighboring countries. Other counties are Vihiga, Kakamega, Bungoma and Busia county. In this regard, these regions were given priority in SGR development based on population economic activity distribution

Tourism contributes significantly to Kenya's GDP, and completion of the SGR is timely as foreign arrivals have declined because of perceived insecurity (Nduire, 2018). The coast region is the most popular destination for domestic tourists, but challenges related to road travel have been a significant hindrance to the realization of full potential in domestic tourism. The Mombasa - Nairobi SGR as a low cost, convenient, quick and secure mode of transport coupled with breath-taking scenery along its path, particularly the stretch that runs through the Tsavo and Nairobi National Parks, has increased the number of international and domestic visitors to the destination (Nduire, 2018; Mwende, 2017). Towns such as Naivasha and Narok

will take a few minutes by train from Nairobi and make it easier for domestic and foreign tourists to experience everything these tourist towns and their surroundings have to offer.

Kenya neighbours landlocked countries of South Sudan and Uganda. Therefore, rapid clearance from Mombasa port, lower transportation costs, faster delivery of cargo would make Kenya the chosen entry point and export route for other nations such as Rwanda and Burundi. Thus having a positive impact on the economy.

\section{Negative Impacts of the SGR development}

Regardless of its many benefits to Kenya, SGR has also been criticised for being not cost effective to make meaningful economic sense in the immediate future. Mwende (2017) observes that earlier studies on the SGR revealed that its benefits will be marginal and that the project was too expensive, only justified by optimistic traffic and income projections (Mwende, 2017). A local daily 'The Standard' (2014), reported that a report by the World Bank cautioned that investment in the SGR would only 
make economic sense if it receives between 20 million and 55 million tons of additional rail freight in a year (The Standard, 2014). Currently, it moves an average of 12 million tonnes per year, a figure $40 \%$ below the project's breakeven point of 20 million tonnes. Given that most of the new railway's revenue will come from cargo transportation, KRC will have to provide incentives for business people to move their freight through the facility, considering that 95 per cent of all cargo to and from Mombasa port is currently transported by road. In the face of competition from truckers, the SGR cargo sector has struggled for revenue, triggering a concerted government campaign to move cargo to the rails in a bid to make sense of SGR investment. Kenya requires additional cash from the railway undertaking to ease the burden on taxpayers to pay to the Chinese company running the SGR (Muthama, 2019; Fick, 2018). Kenya's National Treasury is also seeking more income from the SGR sector to help offset loans borrowed to construct the multi-billion-shilling railway line.

New policies and legislative frameworks are necessary to provide for a certain amount of freight to be transported by rail away from the roads. In 2015, the port of Mombasa handled 26 million tons of cargo, which means that the SGR must win all cargo currently transported from Mombasa by road (Ilako, 2019). Although the SGR is a vital project expected to bring in various socio-economic benefits and the country's GDP growth, it is a two-faced sword with demerits.

The SGR has been tagged as one of the most expensive infrastructural investments that the Kenya government has invested in recent times and has increased Kenya's external debt significantly. It was observed that public debt continues to increase and is currently at 60 percent of GDP inching unsustainable levels. The debt situation is so alarming that Kenya has been placed on its debt-distress watch list by the IMF, (Fick, 2018) and this is expected to exceed USD 70bn by 2022. The Kenya national debt stood at USD 51 billion by June 2018, out of which USD 25billion was domestic debt (Muthama, 2019; Mghenyi \& Mudi, 2017).

Ballooning public debt has reached alarming proportions, piling pressure on taxpayers. IMF has intimated that borrowing is raising Kenya's fiscal vulnerabilities and increased interest payments (Fick, 2018). Whereas there is nothing wrong with borrowing, the borrower is a slave to the lender, and the public wage bill has become a big headache to the Government of Kenya. The government has rolled out steps to improve revenue collection for loan repayment to remedy the situation, such as the implementation of VAT on formerly zero-rated goods, thus increasing living costs among the Kenyan population (Fick, 2018; Ilako, 2019; Muthama, 2019).

The SGR engines are diesel-powered and therefore pollution from exhaust emissions, smoke, oil spillage, waste materials, vibration and noise from machinery and locomotives during the construction phase and subsequent service of the railway is bound to occur. The process of development will and has resulted in the degradation 
and loss of water bodies, agricultural land, crops and natural vegetation. Moreover, as they wind their way through the Tsavo and Nairobi National Parks, the SGR trains pose a danger to wildlife along the corridors of travel during and after the construction. To date, trains have killed a number of elephants, lions, buffaloes, among others (Mwendwa, 2017; Mangat, 2016).

In addition, reduced travel time and costs between Mombasa and Nairobi, coupled with safer traveling environments, the SGR will become the preferred transport mode for cargo owners and passengers hence taking a large number of tracks off the highways. Such developments will significantly result in market disruption amongst freight companies. Unfortunately, the positive aspects of the SGR project on the flipside will result to reduced trade and loss of revenue for heavy haulage truck and passenger transport leading to job loss for drivers, turn boys and truck loaders (Mghenyi \& Mudi, 2017).

As SGR edges heavy trucks in long-distance freight transport, towns and market centres that rely heavily on trucks and related traffic for business opportunities will be at risk of economic collapse. This includes small and medium-sized enterprises such as hotels, bars, lodgings, shopping facilities for fast-moving consumer goods, garages and other roadside vendors who will lose customers. The ruin of townships along major freight motorways, the loss of livelihoods for shop owners, mechanics, oil recyclers and waiters would imminently compel them to move or change their lifestyle or career-which is costly and time-consuming (Mghenyi \& Mudi, 2017; Ilako, 2019).

Last but not least, the resettlement of people, businesses, and social amenities because of infrastructure growth has become a usual occurrence in Kenya along the SGR development route. While those displaced have been adequately compensated, moving from the usual place of residence or ancestral heritage to a new place of life can be a daunting task even with adequate compensation.

\section{Conclusion}

The development of the SGR is in tandem with the development strategies of other East African Countries. Despite the financial constraints the countries are facing, infrastructural development is the backbone of many economic activities and sustainable socio-economic development of landlocked and marginalized regions of Kenya and the broader East African Region. For Kenya, the SGR is a priority area identified under Kenya vision 2030 and the National Spatial Plan of 2015 to 2045, as foundation for the realization of a double-digit annual economic growth rate.

Although, over the years, Kenya had instituted fragmented and piecemeal infrastructural developments, the SGR is undoubtedly among the most significant and 
most impactful of contemporary infrastructural developments in the region. Its development has been integrated into national spatial planning for sustainable development with the rail route targeting regions with viable populations and sustainable economic activities. However, some criticisms revolve around the ballooning borrowing for infrastructural financing and lack of priority in development projects. In this regard, governments should prioritize projects and initiatives for implementation to reduce the taxation burden and excessive public borrowing that can quickly get the country into a debt trap. Nevertheless, the SGR will significantly influence positive change in the socio-economic spheres while presenting potential challenges in the management of landscapes it traverses.

\section{References}

[1.] Bujdosó, Z. - Dávid, L. - Varga, D. - Pénzes, J. - Gyurkó, Á. - Zhakupov, A. (2015): Tourism Development And Cross-Border Cooperation.The Hungarian-Romanian Border Region Geojournal Of Tourism And Geosites, Vol. 16. No. 2 153-163. p. Paper: 16103-178.

[2.] Dávid, L. - Bujdosó, Z. - Tóth, G. (2008): Tourism planning in the HajdúBihar - Bihor Euroregion In: Süli-Zakar, I (szerk.) Neighbours and partners: on the two sides of the border Debrecen, Magyarország : Kossuth Egyetemi Kiadó, pp. 323-332.

[3.] Fick, M. (2018, OCTOBER 24). IMF bumps Kenya's debt distress risk to moderate from low. (G. Obulutsa, \& D. Holmes, Editors) Retrieved from Reuters: https://af.reuters.com/article/investingNews/idAFKCN1MY178OZABS

[4.] Ilako, C. (2019, February 23). SGR freight Services too Pricey for Business. Retrieved from The Star: https://www.the-star.co.ke/counties/2019-02-23sgr-freight-services-too-pricey-for-business/

[5.] Kenya Railways Corporation. (2019, June 02). Madaraka Express - Online Booking. Retrieved from Madaraka Express Online booking: https://metickets.krc.co.ke/

[6.] Kenya Railways Corporation. (2019, June 3). Madaraka Freight Service. Retrieved from Kenya Railways Corporation: http://krc.co.ke/

[7.] Mangat, R. (2016, DECEMBER 31). Tsavo elephants in collision with standard gauge railway. Retrieved from The East African:

[8.] https://www.theeastafrican.co.ke/magazine/Tsavo-elephants-in-collisionwith-standard-gauge-railway/434746-3502644-wo0wd7/index.html

[9.] [8.] Mghenyi, C., \& Mudi, M. (2017, June 19). The good, the bad and the ugly of the SGR. Retrieved from The Star: https://www.the- 
star.co.ke/news/big-read/2017-06-19-the-good-the-bad-and-the-ugly-ofthe-sgr/

[10.] Ministry of Transport, Infrastructure Housing, Urban Development, and Public Works. (2019, June 02). State Department of Transport and Infrastructure. Retrieved from Ministry of Transport, Infrastructure Housing, Urban Development and Public Works: http://transport.go.ke/

[11.] Muthama, J. (2019, April 29). Kenya's public debt has hit worrying level. Retrieved from The Standard Media:

https://www.standardmedia.co.ke/ureport/article/2001323153/kenya-spublic-debt-has-hit-worrying-level

[12.] Mwende, J. (2017, June 1). Benefits of Mombasa-Nairobi standard gauge railway. Retrieved from construction

[13.] Kenya: https://www.constructionkenya.com/2056/benefits-standardgauge-railway/

[14.] Mwendwa, M. (2017, January 4). SGR Will Destroy the Ecology of Nairobi National Park, Experts Warn. Retrieved from Talk Africa: http://www.talkafrica.co.ke/sgr-will-destroy-the-ecology-of-nairobinational-park-experts-warn/

[15.] National Council for Population and Development. (2017). The state of Kenya Population 2017; the populaion factor in transformative change i development in Kenya. Nairobi: Government Printers.

[16.] Nduire, J. (2018, October 17). Positive impact of SGR on the Kenyan economy. Retrieved from Construction Kenya:

https://www.constructionkenya.com/3383/positive-impact-sgr-kenyaneconomy/

[17.] The Republic of Kenya. (2005, June 14). About Vision 2030. Retrieved March 20, 2019, from vision2030.go.ke: https://vision2030.go.ke/aboutvision-2030/

[18.] The Republic of Kenya. (2015, April 08). Kenya National Spatial Plan (2015-2045). Retrieved March 28, 2019, from Kenya Vision 2030: https://vision2030.go.ke/publication/kenya-national-spatial-plan-2015$2045 /$

[19.] The Standard. (2014, February 2). Why the World Bank backed out of project. Retrieved from The Standard Media:

https://www.standardmedia.co.ke/

[20.] World Bank. (2019, March 12). World Bank national accounts data; GDP per capita. Retrieved from The world Bank:

https://data.worldbank.org/indicator/NY.GDP.PCAP.CD?locations=KE 
Authors:

Juma Leanard Otwori

$\mathrm{PhD}$ in Regional Sciences Student

Szent István University

Pátér Károly Ut1

2100, Gödöllö, Hungary

Leanard.Juma@phd.uni-szie.hu

Adol Gogo Fredrick

$\mathrm{PhD}$ in Regional Sciences Student

Szent Istvan University

Pater Karoly Ut1

2100, Godollo, Hungary

Fredrick.Gogo@phd.uni-szie.hu

Abdulkadr Ahmed Abduletif

$\mathrm{PhD}$ in Regional Sciences Student

Szent Istvan University

Pater Karoly Ut1

2100, Godollo, Hungary

ahmedabduletifabdulkadr@su.edu.et

Prof. Lóránt Dénes Dávid

Dr. Habil

PhD Regional Sciences

Szent Istvan University

Pater Karoly Ut1

2100, Godollo, Hungary 